\title{
Pregnancy in Mice Lacking the Vitamin D Receptor: Normal Maternal Skeletal Response, But Fetal Hypomineralization Rescued by Maternal Calcium Supplementation
}

\author{
KATRIEN RUMMENS, SOPHIE J. VAN CROMPHAUT, GEERT CARMELIET, ERIK VAN HERCK, \\ RITA VAN BREE, INGRID STOCKMANS, ROGER BOUILLON, AND JOHAN VERHAEGHE \\ Department of Obstetrics and Gynaecology [K.R., R.v.B., J.V.], and Laboratorium voor Experimentele \\ Geneeskunde en Endocrinologie [S.J.V.C, G.C., E.V.H., I.S., R.B., J.V.], Katholieke Universiteit Leuven, \\ 3000 Leuven, Belgium
} \begin{abstract}
ABS
Fetal mineralization appears to be driven by the pregnancy-
induced stimulation of intestinal Ca absorption. We thus hypothesized that mineralization would be impaired in fetuses of mice that lack the vitamin D receptor (VDR). Here we report on the maternal response to pregnancy, and the fetal mineralization, in mice with a homozygous disruption of the VDR gene (VDR-/-) mated with wild-type (wt) males. We found that $V D R-/-$ mice show mild hypocalcemia, clear rickets and osteomalacia on bone histomorphometry, lower cortical bone density on quantitative tomography, and reduced concentrations of calbindin- $\mathrm{D}_{9 \mathrm{k}}$ $\left(\mathrm{CaBP}-\mathrm{D}_{9 \mathrm{k}}\right)$ in duodenal mucosa and kidney. The skeletal response to pregnancy was comparable in $w t$ and $V D R-/-$ mice; duodenal $\mathrm{CaBP}-\mathrm{D}_{9 \mathrm{k}}$ concentrations increased during pregnancy in $V D R-/-$ as in $w t$ mice, but remained $40 \%$ lower than in $w t$ mice. We confirmed our hypothesis that mineralization is defective in $\mathrm{d} 18.5 \mathrm{VDR}+/-$ fetuses of $V D R-/-$ mice, both by whole-body $\mathrm{Ca}$ determination and histomorphometric evaluation; the number of osteoclastic cells in bone was increased. The fetuses were hypercalcemic and had a 5-fold increase in circulating $1,25(\mathrm{OH})_{2} \mathrm{D}_{3}$. We then studied pregnancies in $V D R-/-$
\end{abstract}

females, mated with $w t$ males, fed a high $\mathrm{Ca} / \mathrm{P} /$ lactose rescue diet during pregnancy. The rescue diet normalized the mineralization, the number of osteoclastic cells, and plasma $\mathrm{Ca}$ and $1,25(\mathrm{OH})_{2} \mathrm{D}_{3}$ concentrations in the fetuses. We interpret the data as evidence that, to ensure normal fetal mineralization, the maternal VDR-dependent intestinal Ca absorption can be substituted by passive $\mathrm{Ca}$ absorption entrained by a higher $\mathrm{Ca}$ intake. Alternatively or additionally, elevated $1,25(\mathrm{OH})_{2} \mathrm{D}_{3}$ in utero may disturb bone development. (Pediatr Res 54: 466-473, 2003)
Abbreviations
1,25(OH)2D3, 1,25-dihydroxyvitamin $\mathrm{D}_{3}$ CaBP-D $\mathbf{D}_{\mathbf{9}}$ calbindin- $\mathrm{D}_{9 \mathrm{k}}$
$\mathrm{CV}$, coefficient of variation
ko, knock-out
QCT, quantitative computed tomography
TRAP, tartrate-resistant acid phosphatase
VDR, vitamin D receptor
$w t$, wild type

Increased intestinal $\mathrm{Ca}$ absorption during pregnancy appears to be a major determinant of fetal mineralization (1). The rise in $\mathrm{Ca}$ absorption is largely the result of a more efficient ATP-dependent, transcellular $\mathrm{Ca}$ absorption, which is vitamin D-receptor (VDR)-dependent. The concentrations of circulating $1,25(\mathrm{OH})_{2} \mathrm{D}_{3}$ and duodenal VDR increase during preg-

Received August 8, 2002; accepted February 24, 2003

Correspondence: Dr. Johan Verhaeghe, Department of OB/GYN, U.Z. Gasthuisberg, Herestraat 49, 3000 Leuven, Belgium; e-mail: johan.verhaeghe@uz.kuleuven.ac.be

K. Rummens and S.J. Van Cromphaut are supported by grants ("Aspirant Navorser") from the Fonds voor Wetenschappelijk Onderzoek-Vlaanderen (Belgium). This work was supported by a grant (G.0225.00) from the Fonds voor Wetenschappelijk OnderzoekVlaanderen (Belgium).

DOI: 10.1203/01.PDR.0000081302.06915.D3 nancy in rats, as does the duodenal expression of the calbindin$\mathrm{D}_{9 \mathrm{k}}$ gene $\left(\mathrm{CaBP}-\mathrm{D}_{9 \mathrm{k}}\right)$ (2). CaBP- $\mathrm{D}_{9 \mathrm{k}}$ is involved in the transport of $\mathrm{Ca}$ across the epithelia of the intestine (3), the distal tubules of the kidneys (4), and the syncytiotrophoblast (5). Following $\mathrm{Ca}$ influx through the apical membrane, which is facilitated by the epithelial $\mathrm{Ca}^{2+}$ channels 1 and 2, CaBP- $\mathrm{D}_{9 \kappa}$ serves as a "ferry" for Ca to cross the cytosol. Ca is then actively extruded at the basal membrane by a $\mathrm{Ca}^{2+}$-ATP-ase in the duodenum or placenta, and by a $\mathrm{Ca}^{2+}$-ATP-ase and $\mathrm{a} \mathrm{Na}^{+}-\mathrm{Ca}^{2+}-$ exchanger in the kidneys (3-6).

Several strains of mice with a disrupted VDR gene have been generated, including the Tokyo-strain (7), the Bostonstrain (8) and the Leuven-strain (9). VDR-null mice show rickets and osteomalacia, with abnormal $\mathrm{Ca}$ homeostasis in- 
cluding hypocalcemia and hyperparathyroidism (7-9). The expression of the CaBP- $\mathrm{D}_{9 \mathrm{k}}$ gene is reduced in the intestine and kidneys of VDR-null mice $(7,10,11)$, confirming VDRregulation (12). The abnormalities become manifest only in the late neonatal period or after weaning $(7,8)$. Reversing hypocalcemia and hyperparathyroidism, by a diet enriched with $\mathrm{Ca}$, phosphate $(\mathrm{P})$ and lactose, normalizes rickets and osteomalacia $(13,14)$.

Female VDR-null mice have a variable reduction of fertility: Tokyo-VDR-null mice are infertile $(7,15)$, whereas pregnancy is possible in Leuven-VDR-null mice. Data on pregnancy in mice lacking the VDR gene are elusive, and we hypothesized that fetal mineralization would be reduced, given the pivotal role of intestinal $\mathrm{Ca}$ absorption. The effect of VDR gene disruption on placental $\mathrm{CaBP}-\mathrm{D}_{9 \mathrm{k}}$ is uncertain. A study in normocalcemic nutritionally vitamin $\mathrm{D}$ (D)-deficient rats showed normal placental $\mathrm{CaBP}_{-} \mathrm{D}_{9 \mathrm{k}}$ gene expression, compared with D-replete rats (16). Here we investigated the effect of VDR gene disruption on the maternal skeletal response, maternal and placental $C a B P-D_{9 k}$ concentrations and fetal mineralization. In an additional experiment, we studied the effect of a 'rescue' diet enriched with $\mathrm{Ca}, \mathrm{P}$ and lactose on CaBP- $\mathrm{D}_{9 \mathrm{k}}$ concentrations and fetal mineralization in VDR-null mice.

\section{MATERIALS AND METHODS}

Animals. The experiments were approved by the ethical committee for animal research at the K.U. Leuven. Leuven VDR-null mice $(V D R-/-)$ were generated by homozygous targeted ablation of exon 2 of the VDR-gene in embryonic stem cells, as described earlier (9). The animals received a standard murine diet, containing $1.04 \% \mathrm{Ca}, 0.76 \% \mathrm{P}$, and 2000 IU D/kg (Carfil, Oud-Turnhout, Belgium). Six-week-old female $V D R-/-$ mice, born from $V D R+/-$ mothers and $V D R-/-$ fathers, were mated overnight with wild-type (wt) males, so that the fetuses were heterozygous for VDR $(V D R+/$ $-)$. Pregnant $w t$ mice and their fetuses, as well as nonpregnant female $V D R-/-$ and $w t$ mice of the same age served as controls. The animals received bone fluorochrome labeling with calcein (Sigma Chemical Co., St. Louis, MO, U.S.A.), 50 $\mu \mathrm{g}$ i.p., $4 \mathrm{~d}$ and $24 \mathrm{~h}$ before surgery. In a separate experiment, pregnant $V D R-/-$ mice were fed a high lactose, and $\mathrm{Ca}$-and P-enriched murine diet, containing $2.0 \% \mathrm{Ca}, 1.25 \% \mathrm{P}, 2200 \mathrm{IU}$ $\mathrm{D} / \mathrm{kg}$, and $20 \%$ lactose (VDR $-/-$ rescue diet group) (Teklad, Madison, WI, U.S.A.) from diagnosis of pregnancy (i.e., the presence of a copulation plug).

On $\mathrm{d} 18.5$, the mice were anesthetized with an i.p. injection of sodium pentobarbital $(0.6 \mu \mathrm{g} / \mathrm{g}$ body weight). In pregnant animals, the uterus was exposed from left to right, and the fetuses were delivered through small uterine incisions. They were bled by an axillary incision, with the umbilical cord still attached to the placenta; fetal blood was pooled per litter. All fetuses and placentas were subsequently weighed. Both tibiae of the first 3 fetuses were removed for histomorphometry. The remaining fetuses were eviscerated, and stored at $-20^{\circ} \mathrm{C}$ for measurement of the $\mathrm{Ca}$ content. Maternal blood was sampled by cardiac puncture, and the mice were euthanized. The first placenta was fixed in p-formaldehyde $4 \%$ in cacodylate buffer $0.1 \mathrm{M}(\mathrm{pH} 7.2)$ for $24 \mathrm{~h}$ at $4^{\circ} \mathrm{C}$, rinsed in $0.1 \mathrm{M}$ cacodylate buffer ( $\mathrm{pH} 7.2$ ) for $24 \mathrm{~h}$, and then kept in ethanol $70 \%$ at $4{ }^{\circ} \mathrm{C}$, until embedding for $\mathrm{CaBP}_{-} \mathrm{D}_{9 \mathrm{k}}$ immunohistochemistry. The other placentas, and the maternal duodenum and left kidney were rapidly removed, snap frozen in liquid nitrogen and stored in $-80^{\circ} \mathrm{C}$ for determination of CaBP- $\mathrm{D}_{9 \mathrm{k}}$ protein content. The left tibia was kept in Burkhardt's fixative for $24 \mathrm{~h}$ at $4^{\circ} \mathrm{C}$, and then kept in ethanol $100 \%$, until embedding for histomorphometry; the right tibia was fixated in p-formaldehyde $2 \%$ in cacodylate buffer $0.1 \mathrm{M}(\mathrm{pH} 7.2)$ for $24 \mathrm{~h}$, and then kept on cacodylate buffer $0.1 \mathrm{M}(\mathrm{pH} 7.2)$ at $4^{\circ} \mathrm{C}$, until decalcification. The femora were stored for quantitative computed tomography (QCT).

Assays. Total Ca in plasma was measured colorimetrically (Sigma Chemical Co. Diagnostics, St. Louis, MO, U.S.A.). $1,25(\mathrm{OH})_{2} \mathrm{D}_{3}$ was measured by a RIA-kit (Diasorin, Stillwater, MN, U.S.A.); plasma samples of $w t$ adult mice and of the fetal mice were pooled in a consecutive 2-by-2 fashion for this assay. Osteocalcin was measured by an in-house RIA with mouse osteocalcin as the standard and a rabbit polyclonal antiserum (17). Intra- and inter-assay coefficients of variation $(\mathrm{CV})$ are $5.9 \%(n=10)$ and $5.2 \%(n=9) . \mathrm{CaBP}^{-\mathrm{D}_{9 \mathrm{k}}}$ protein content was measured in homogenates of the duodenum, kidney and placenta by RIA, using CaBP- $_{9 \mathrm{k}}$, purified from rat duodenum, as the standard (12) and a polyclonal antiserum raised in rabbits (batch R152489, kindly donated by M.E. Bruns, Charlottesville, VA, U.S.A.), as described previously (18); values were expressed per total protein, which was measured colorimetrically (Pierce BCA Protein Assay, Rockford, IL, U.S.A.). The detection limit is $2.5 \mathrm{ng} / \mathrm{mL}$ for CaBP$\mathrm{D}_{9 \mathrm{k}}$ and $0.1 \mathrm{mg} / \mathrm{mL}$ for total protein; intra- and inter-assay CV are $5.2 \%$ and $6.3 \%$, respectively.

Placental CaBP-D9k immunohistochemistry. Placental CaBP-D9k immunohistochemistry was performed as described (18); the anti-rat $\mathrm{CaBP}-\mathrm{D}_{9 \mathrm{k}}$ antiserum was diluted 1:32,000.

Bone studies. The dry weight of the adult femora was obtained after dehydrating (in ethanol and diethylether for several days) and drying $\left(24 \mathrm{~h}\right.$ at $\left.100^{\circ} \mathrm{C}\right)$ the bones. QCT of the adult femora was measured with a XCT Bone Scanner (Norland, Fort Atkinson, WI), as described (19). Trabecular bone density was measured in an inner area of $25 \%$ of the total cross-sectional area, at $0.75,1.0$ and $1.25 \mathrm{~mm}$ from the distal growth plate; the average value was calculated. Cortical bone density and the endocortical and pericortical perimeters were measured at $7 \mathrm{~mm}$ from the distal growth plate. Betweenmeasurement $\mathrm{CV}$ is $<1 \%$.

Eviscerated fetuses were dried $\left(24 \mathrm{~h}\right.$ at $\left.100^{\circ} \mathrm{C}\right)$ and ashed in a muffle furnace at $600^{\circ} \mathrm{C}$. The ash of each fetus was weighed and dissolved in $\mathrm{HCl}$; $\mathrm{Ca}$ was measured by colorimetry in diluted ash and the fetal $\mathrm{Ca}$ content was calculated as a percentage of fetal ash and per dry body weight after evisceration (18).

Histomorphometry of adult tibiae was performed as described previously for rat (20) and guinea pig tibiae $(19,21)$, with adaptations for mouse bones. The undecalcified left proximal tibia was embedded in methylmethacrylate, and $4 \mu \mathrm{m}$ thick longitudinal sections were cut. Three sections were as- 
sessed per animal, with $100 \mu \mathrm{m}$ in between. Static and dynamic morphometry were performed using a KS 400 Image Analyzing Computer (Carl Zeiss, Hallbergmoos, Germany) or a VIDAS 21 Image Analyzing Computer (Kontron, Munich, Germany). Standardized measurements, nomenclature and abbreviations were used (22). Trabecular bone volume (BV/TV) was measured in von Kossa-stained sections, in 2 consecutive fields in the vertical axis of the central metaphysis at magnification $\times 300$, excluding the primary spongiosa. Sections stained with a modified Goldner-trichrome were used for the measurement of osteoid surface (OS/BS) and thickness (O.Th) and the growth plate width (GPW). Growth plate width was measured over the full length of the growth plate at magnification $\times 300$. The other measurements were performed in the secondary spongiosa, in as many fields as possible, at magnification $\times 300$, excluding the endocortical and subcortical bone surfaces: $4.0 \pm 0.1$ fields (mean \pm SEM, $n=156$ ) were assessed per section, corresponding to $12,657 \pm 782 \mu \mathrm{m}$ trabecular bone surface. For the fluoromicroscopic measurement in unstained sections of double- (dLS/BS) and singlelabeled (sLS/BS) surfaces and the mineral apposition rate (MAR), we measured $6 \pm 1$ double labels per section; the mineral apposition rate was measured at 3 equidistant points per double label. If a particular section contained no double fluorochrome labels, the mineral apposition rate was given a missing value. The mineral formation rate, surface-referent (MFR/BS), was calculated as the mineralizing surface (MS/BS $=\mathrm{dLS} / \mathrm{BS}+1 / 2 \mathrm{sLS} / \mathrm{BS}) \times$ mineral apposition rate $\times \pi / 4$ (to correct for the obliquity of the sections).

The right proximal tibiae of adult mice were decalcified, embedded in paraffin, and $3 \mu \mathrm{m}$-thick sections were cut. The sections were stained for tartrate-resistant acid phosphatase (TRAP) as described previously (20), but with incubation for $1 \mathrm{~h}$ in Tris after deparaffination and with an incubation time of 40 min in naphthol AS-BI phosphate. The measurements (TRAPS/BS) were performed exactly as for the osteoid surface.

Fetal (undecalcified) tibiae were embedded in paraffin, and 3 $\mu \mathrm{m}$-thick sections were produced. Three sections per fetus were assessed, with $18 \mu \mathrm{m}$ in between. We measured the mineralized bone volume, relative to the total bone volume (BV/TV) in von Kossa-stained sections, at magnification $\times 150$. In TRAP-stained sections, we counted the TRAPpositive cells in the trabecular bone area, at magnification $\times 600$. We also measured the area occupied by hypertrophic chondrocytes relative to the total chondrocyte area of the growth plate at magnification $\times 150$, as described previously in guinea-pig fetuses (19) and in $V D R-/-$ mice (8). Dynamic histomorphometry could not be performed in fetuses, because the calcein labeling pattern was indistinct.

Data analysis. Data analysis was performed with a software program (NCSS, Kaysville, UT, U.S.A.). In $w t$ and $V D R-/-$ adult animals, the effects of genotype and pregnancy were compared by two-factor ANOVA. If a significant interactive effect was detected ( $p<0.05)$, one-way ANOVA was performed to confirm an overall significant effect, followed by Fisher's LSD multiple comparison test to detect differences between individual groups. Fetuses of the 3 groups ( $w t$, $V D R-/-$ and $V D R-/-$ rescue) were analyzed by one-way ANOVA; if $p<0.05$, Fisher's LSD multiple comparison test was used to detect significant differences between individual groups. Where appropriate, 2 individual groups were compared by unpaired $t$ tests, taking into account the variance of the data.

\section{RESULTS}

Phenotype of VDR-/- mice. VDR-ablation did not affect body weight, but, as expected, plasma Ca levels were lower while $1,25(\mathrm{OH})_{2} \mathrm{D}_{3}$ levels were markedly higher (Table 1$)$. The femoral dry weight was not altered in $V D R-/-$ mice. However, on QCT analysis, cortical thickness $(-15 \%)$ and cortical bone density $(-10 \%)$ were reduced, whereas trabecular bone density was unchanged (Table 2). Histomorphometry of trabecular bone showed the typical signs of rickets (increased growth plate width) and osteomalacia (increased osteoid surface and thickness); trabecular bone volume was also increased, as was the bone surface covered by TRAP-positive cells (Table 3). But we found no effect of VDR ko on mineralizing surface, mineral apposition rate or mineral formation rate on dynamic morphometry.

In $w t$ mice, $\mathrm{CaBP}-\mathrm{D}_{9 \mathrm{k}}$ concentrations were 5-fold higher in the duodenum than in the kidney, and 3-fold higher than in the placenta (Fig. 1). VDR ko lowered duodenal $\mathrm{CaBP}_{-} \mathrm{D}_{9 \mathrm{k}}$ by $35 \%$ to $40 \%$, and renal $\mathrm{CaBP}-\mathrm{D}_{9 \mathrm{k}}$ by $90 \%$.

Table 1. Body weight, and plasma calcium $(\mathrm{Ca})$ and 1,25-dihydroxyvitamin $\mathrm{D}_{3}\left[1,25(\mathrm{OH})_{2} \mathrm{D}_{3}\right]$ in nonpregnant and pregnant wild type (wt) and VDR-null mice, and in pregnant VDR-/- rescue mice

\begin{tabular}{|c|c|c|c|c|c|c|c|c|}
\hline & \multicolumn{2}{|c|}{ wt } & \multicolumn{2}{|c|}{ VDR-null } & \multicolumn{3}{|c|}{ Two-factor ANOVA } & \multirow[b]{2}{*}{ VDR $-1-$ rescue pregnant } \\
\hline & Nonpregnant & Pregnant & Nonpregnant & Pregnant & Genotype & Pregnancy & Interaction & \\
\hline $\begin{array}{l}\text { Body weight } \\
\text { (g) }\end{array}$ & $\begin{array}{c}21.4(0.7) \\
(n=14)\end{array}$ & $\begin{array}{l}38.0(1.6) \\
(n=14)\end{array}$ & $\begin{array}{l}23.0(0.6) \\
(n=15)\end{array}$ & $\begin{array}{l}40.8(1.5) \\
(n=15)\end{array}$ & NS & $*$ & NS & $\begin{array}{c}32.9(1.4) \dagger \\
\quad(n=8)\end{array}$ \\
\hline $\begin{array}{l}\text { Plasma Ca } \\
\quad(\mathrm{mg} / 100 \mathrm{~mL})\end{array}$ & $\begin{array}{l}8.9(0.1) \\
(n=6)\end{array}$ & $\begin{array}{c}10.0(0.3) \\
(n=6)\end{array}$ & $\begin{array}{l}8.1(0.3) \\
(n=7)\end{array}$ & $\begin{array}{l}9.1(0.2) \\
(n=5)\end{array}$ & $*$ & $*$ & NS & $\begin{array}{c}10.1(0.3) \dagger \dagger \\
(n=8)\end{array}$ \\
\hline $\begin{array}{c}1,25(\mathrm{OH})_{2} \mathrm{D}_{3} \\
(\mathrm{pg} / \mathrm{mL})\end{array}$ & $\begin{array}{l}32^{\mathrm{A}}(6) \\
(n=5)\end{array}$ & $\begin{array}{l}85^{\mathrm{A}}(12) \\
(n=6)\end{array}$ & $\begin{array}{c}2330^{\mathrm{B}}(269) \\
\quad(n=8)\end{array}$ & $\begin{array}{c}1032^{\mathrm{C}}(72) \\
(n=9)\end{array}$ & $*$ & $*$ & $*$ & $\begin{array}{c}100(-) \dagger \\
(n=8)\end{array}$ \\
\hline
\end{tabular}

Data are means (SEM). The number of data $(n)$ is shown. Statistical procedure: the effects of genotype and pregnancy were studied by two-factor ANOVA. $* p \leq 0.01$; NS: not significant. If an interactive effect between both was detected $(p<0.05)$, one-way ANOVA was performed to confirm an overall significant effect, followed by Fisher's LSD multiple comparison test to detect differences between individual groups. Post-hoc comparisons that were significantly different are denoted by different capital letters in superscript (all $p<0.01$ ). Pregnant VDR-/- rescue mice were compared with pregnant wt and VDR-null mice, respectively, by unpaired t-tests. $\dagger \mathrm{VDR}-1-$ rescue vs. VDR-null $(\dagger p<0.01$; $\dagger \dagger p<0.05)$. 
Table 2. QCT analysis and dry weight of the femur in nonpregnant and pregnant wild type (wt) and VDR-null mice, and in pregnant $V D R-/-$ rescue mice

\begin{tabular}{|c|c|c|c|c|c|c|c|}
\hline & \multicolumn{2}{|c|}{ wt } & \multicolumn{2}{|c|}{ VDR-null } & \multicolumn{2}{|c|}{ Two-factor ANOVA } & \multirow[b]{2}{*}{ VDR $-/-$ rescue pregnant } \\
\hline & Nonpregnant & Pregnant & Nonpregnant & Pregnant & Genotype & Pregnancy & \\
\hline Cortical thickness $(\mu \mathrm{m})$ & $\begin{array}{l}200(4) \\
(n=14)\end{array}$ & $\begin{array}{l}199(3) \\
(n=14)\end{array}$ & $\begin{array}{l}169(6) \\
(n=15)\end{array}$ & $\begin{array}{l}178(5) \\
(n=15)\end{array}$ & * & NS & $\begin{array}{c}234(9) \dagger+\ddagger \\
(n=8)\end{array}$ \\
\hline $\begin{array}{l}\text { Cortical bone density } \\
\left(\mathrm{mg} / \mathrm{cm}^{3}\right)\end{array}$ & $\begin{array}{l}1206(8) \\
(n=14)\end{array}$ & $\begin{array}{l}1200(6) \\
(n=14)\end{array}$ & $\begin{array}{l}1084(21) \\
(n=15)\end{array}$ & $\begin{array}{l}1119(12) \\
(n=15)\end{array}$ & $*$ & NS & $\begin{array}{c}1245(15) \dagger \dagger, \ddagger \\
(n=8)\end{array}$ \\
\hline $\begin{array}{l}\text { Trabecular bone density } \\
\qquad\left(\mathrm{mg} / \mathrm{cm}^{3}\right)\end{array}$ & $\begin{array}{l}134(20) \\
(n=14)\end{array}$ & $\begin{array}{l}202(15) \\
(n=14)\end{array}$ & $\begin{array}{l}146(14) \\
(n=15)\end{array}$ & $\begin{array}{l}188(22) \\
(n=15)\end{array}$ & NS & $*$ & $\begin{array}{l}313(31) \dagger,+ \\
(n=8)\end{array}$ \\
\hline
\end{tabular}

Data are means (SEM). The number of data $(n)$ is shown. Statistical procedure: the effects of genotype and pregnancy in wt and VDR-null mice were studied by two-factor ANOVA. No interactive effects between genotype and pregnancy were detected. $* p<0.01$; NS: not significant. Pregnant VDR $-/-$ rescue mice were compared with pregnant wt and VDR-null mice, respectively, by unpaired t-tests. $\dagger \mathrm{VDR}-/-$ rescue vs. wt $(\dagger p<0.01 ; \dagger \dagger p<0.05) ;+\mathrm{VDR}-/-$ rescue vs. VDR-null (all $p<0.01$ ).

Table 3. Histomorphometry of the proximal tibia in nonpregnant and pregnant wild type (wt) and VDR-null mice

\begin{tabular}{|c|c|c|c|c|c|c|c|}
\hline & \multicolumn{2}{|c|}{$\mathrm{wt}$} & \multicolumn{2}{|c|}{ VDR-null } & \multicolumn{3}{|c|}{ Two-factor ANOVA } \\
\hline \multicolumn{8}{|l|}{ Static } \\
\hline $\mathrm{BV} / \mathrm{TV}(\%)$ & $10(1)$ & $14(1)$ & $13(2)$ & $21(3)$ & $\dagger$ & $*$ & NS \\
\hline OS/BS (\%) & $24(1)$ & $11(2)$ & $45(2)$ & $34(2)$ & $*$ & $*$ & NS \\
\hline O.Th $(\mu \mathrm{m})$ & $4.4(0.3)$ & $3.9(0.1)$ & $6.4(0.1)$ & $5.7(0.2)$ & $*$ & $*$ & NS \\
\hline MS/BS (\%) & $7.5(2.1)$ & $4.0(1.6)$ & $5.1(0.7)$ & $1.3(0.2)$ & NS & $*$ & NS \\
\hline MFR/BS $\left(\mu \mathrm{m}^{3} / \mu \mathrm{m}^{2} / \mathrm{d}\right)$ & $29.4(9.6)$ & $13.6(5.5)$ & $20.7(3.9)$ & $3.2(0.7)$ & NS & $*$ & NS \\
\hline
\end{tabular}

Data are means (SEM). The number of data is as in Table 2. GPW: growth plate width; BV/TV: trabecular bone volume; OS/BS: osteoid surface; O.Th: osteoid thickness; TRAPS/BS: tartrate-resistant acid phosphatase-positive surface; MS/BS: mineralizing surface; MFR/BS: mineral formation rate, surface referent. Statistical procedure: the effects of genotype and pregnancy were studied by two-factor ANOVA. ${ }^{*} p<0.01 ; \dagger p<0.05$; NS: not significant. If an interactive effect between both was detected $(p<0.05)$, one-way ANOVA was performed to confirm an overall significant effect, followed by Fisher's LSD multiple comparison test to detect differences between individual groups. Post-hoc comparisons that were significantly different are denoted by different capital letters in superscript $(p<0.01)$.

Changes during late pregnancy in wt and VDR-/- mice. Plasma Ca was slightly increased in late pregnancy in both wt and VDR $-/-$ mice (Table 1); $1,25(\mathrm{OH})_{2} \mathrm{D}_{3}$ levels rose during wt pregnancy (although this was not significant), whereas $1,25(\mathrm{OH})_{2} \mathrm{D}_{3}$ was lower in pregnant than in nonpregnant ko mice. Body weight, and femoral dry weight (Table 2) increased comparably in wt and VDR-/- mice. On QCT analysis, cortical thickness and bone density did not change, but (metaphyseal) trabecular bone density was increased in pregnant mice. Similarly, on histomorphometry, trabecular bone volume was increased in pregnant compared with nonpregnant mice (Table 3). Furthermore, histomorphometry of trabecular bone showed a pregnancy-associated decline in parameters indicative of bone formation and mineralization: osteoid surface and thickness, and mineralization surface and mineral formation rate. Growth plate width and TRAP-positive surface were unaffected by pregnancy. Overall, there were no significant interactions in the skeletal response to pregnancy between wt and ko mice.

Duodenal CaBP- $\mathrm{D}_{9 \mathrm{k}}$ increased during pregnancy in both $w t$ and $V D R-/-$ animals, but the pregnancy-associated rise in renal CaBP- $\mathrm{D}_{9 \mathrm{k}}$, observed in $w t$ mice, was absent in $V D R-/-$ mice (Fig. 1).

Effects of the rescue diet in pregnant VDR-/- mice. The $\mathrm{Ca} / \mathrm{P} /$ lactose-enriched diet reversed the slight hypocalcemia in
$V D R-/-$ mice on the regular diet, as well as the increased $1,25(\mathrm{OH})_{2} \mathrm{D}_{3}$ concentrations (Table 1). Although body weight was lower in the mice on the rescue diet, femoral dry weight (Table 2) was comparable to that of ko mice on the regular diet. QCT analysis showed that the reduction in cortical bone thickness and density was reversed by the rescue diet; cortical density was also $3 \%$ higher than in pregnant $w t$ mice. In addition, trabecular bone density was 55\% and 66\% higher than in pregnant $w t$ and $k o$ mice on the regular diet, respectively. The rescue diet further reduced duodenal and renal CaBP-D ${ }_{9 \mathrm{k}}$ concentrations (Fig. 1).

Placental parameters in wt and VDR-/- pregnancies. Placental weight was not different among $w t, V D R-/-$ and $V D R-/-$ rescue groups (ANOVA: $p=0.16$ ). In addition, we found no significant differences in the placental CaBP- $D_{9 k}$ concentrations among these 3 groups (Fig. 1). Immunohistochemistry of the placenta showed that $\mathrm{CaBP}-\mathrm{D}_{9} \mathrm{~K}^{-}$-staining was most intense in the intraplacental yolk sac. Staining was equally intense in the visceral and parietal layer of the intraplacental yolk sac, but appeared to be more abundant in the visceral layer. Weak staining was observed in the trophospongium and in the trophospongial islets within the labyrinth, as well as in the trophoblastic giant cells (not shown). On qualitative examination, we found no differences in the staining 

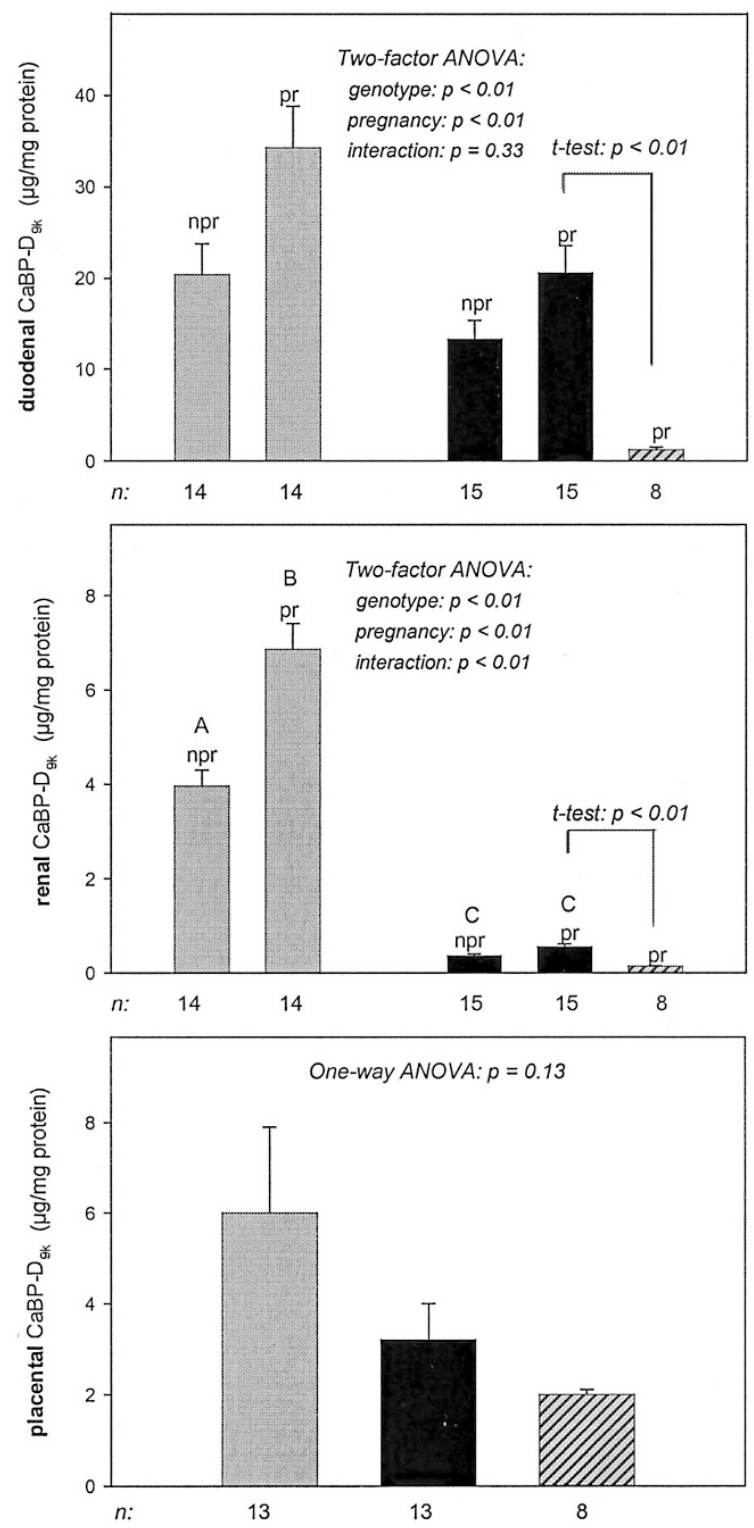

Figure 1. $C a B P-D_{9 k}$ in duodenum, kidney, and placenta of nonpregnant (npr) and d 18.5-pregnant (pr) wt (gray bars) and VDR-null (black bars) mice and pregnant $V D R-/-$ rescue (hatched bars) mice. The number of data $(n)$ is shown below the bars. Statistical analysis: in $w t$ and VDR-null animals, the effects of genotype and pregnancy on duodenal and renal $C a B P-D_{9 k}$ were studied by two-factor ANOVA. An interactive effect between pregnancy and genotype was detected for renal CaBP- $\mathrm{D}_{9 \mathrm{k}}$; therefore, one-way ANOVA was performed to confirm an overall significant difference, followed by Fisher's LSD multiple comparison test to detect differences between individual groups. Posthoc comparisons that were significantly different are denoted by different capital letters on top of the bars $(p<0.01)$. Pregnant VDR-null mice on the rescue diet were compared with VDR-null mice on the regular diet by unpaired $t$ tests.

intensity or localization of $\mathrm{CaBP}-\mathrm{D}_{9 \mathrm{k}}$ in placentas of $w t$, $V D R-/-$, and $V D R-/-$ rescue mice (Fig. 2).

Fetal growth and mineralization, and effect of the rescue diet. There was no difference among the 3 groups in the number of live fetuses per litter [6.9 (0.7) mean (SEM), 7.6 (0.7), and $6.6(0.8)$ in $w t, V D R-/-$, and $V D R-/-$ rescue groups, respectively; ANOVA: $p=0.65$ ], or the number of early (resorptions) or late fetal deaths (ANOVA: $p=0.85$ and
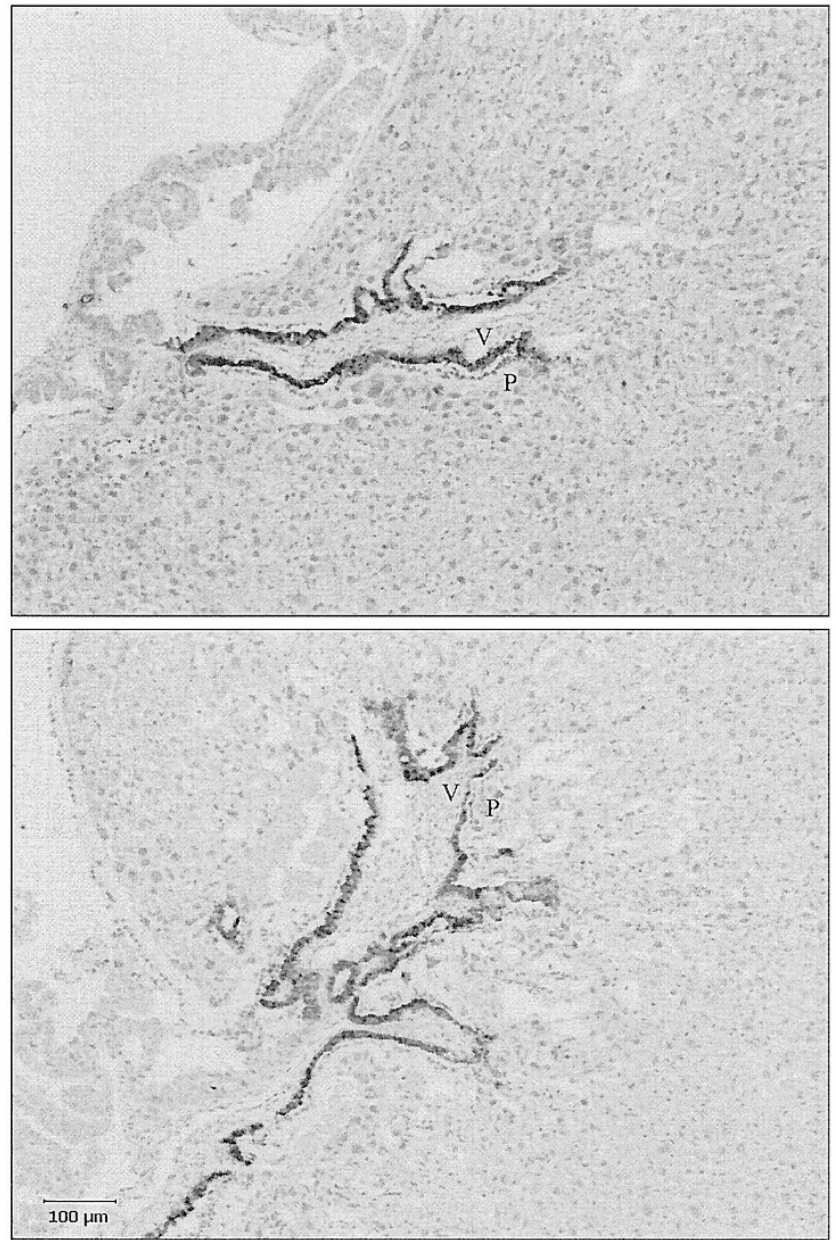

Figure 2. Representative sections of $C a B P-D_{9 k}$ immunohistochemistry in $d$ 18.5-pregnant murine placentas, showing intense staining of the intraplacental yolk sac. Top: placenta of a wt mouse. Bottom: placenta of a VDR-null mouse. $\mathrm{V}$, and P: visceral and parietal layer of the intraplacental yolk sac, respectively. Magnification $\times 100$.

Table 4. Body weight, and plasma calcium (Ca), 1,25-dihydroxyvitamin $D_{3}\left[1,25(\mathrm{OH})_{2} D_{3}\right]$ and osteocalcin in fetuses of wild type (wt), VDR-null and VDR-1- rescue mice

\begin{tabular}{lccc}
\hline & wt & VDR-null & VDR-/- rescue \\
\hline Body weight $(\mathrm{g})$ & $1.14^{\mathrm{A}}(0.01)$ & $1.05^{\mathrm{B}}(0.01)$ & $0.96^{\mathrm{C}}(0.02)$ \\
& $(n=96)$ & $(n=114)$ & $(n=57)$ \\
Plasma Ca $(\mathrm{mg} / 100 \mathrm{~mL})$ & $8.4^{\mathrm{A}}(0.3)$ & $10.5^{\mathrm{B}}(0.9)$ & $7.0^{\mathrm{A}}(0.5)$ \\
& $(n=6)$ & $(n=6)$ & $(n=8)$ \\
& $50^{\mathrm{A}}(6)$ & $247^{\mathrm{B}}(29)$ & $40^{\mathrm{A}}(7)$ \\
$1,25(\mathrm{OH})_{2} \mathrm{D}_{3}(\mathrm{pg} / \mathrm{mL})$ & $(n=4)$ & $(n=4)$ & $(n=4)$ \\
& $29^{\mathrm{A}}(3)$ & $49^{\mathrm{B}}(4)$ & $29^{\mathrm{A}}(4)$ \\
Osteocalcin $(\mathrm{ng} / \mathrm{mL})$ & $(n=14)$ & $(n=15)$ & $(n=8)$ \\
& &
\end{tabular}

Data are means (SEM). The number of data $(n)$ is shown. Statistical analysis: fetuses of the different groups were analyzed by one-way ANOVA; if $p<0.05$, Fisher's LSD multiple comparison test was used to detect differences between individual groups. Post hoc comparisons that were significantly different are denoted by different capital letters in superscript.

$p=0.88$, respectively). Compared with $w t$ fetuses, there was an $8 \%$ reduction in body weight in $V D R+/-$ fetuses on the regular diet, and a $16 \%$ reduction in $V D R+/-$ fetuses of the rescue diet group (Table 4); thus, the rescue diet aggravated the 

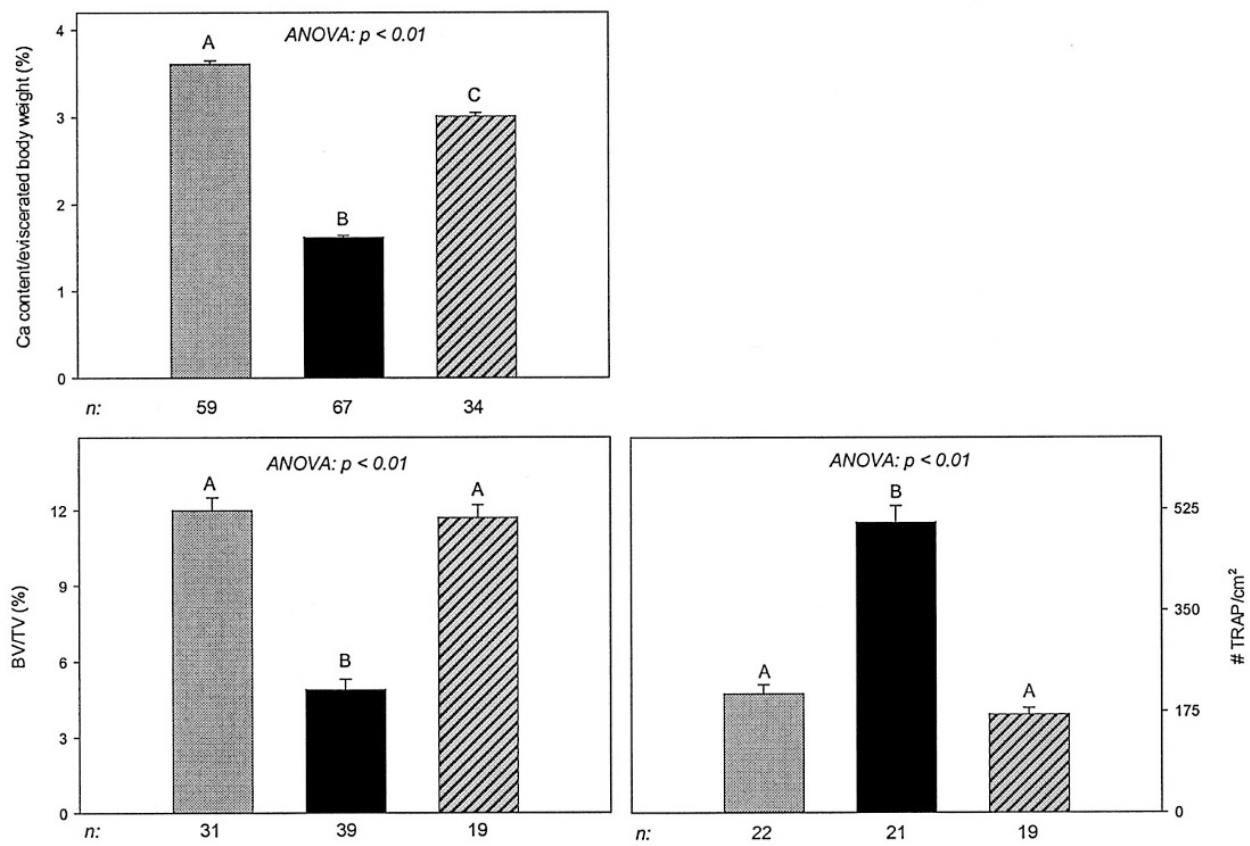

Figure 3. Bone data of fetuses of wt (gray bars), VDR-null (black bars), and VDR-null mice on the rescue diet (hatched bars): BV/TV, mineralized bone volume; TRAP, number of TRAP-positive cells. The number of data $(n)$ is shown below the bars. Statistical analysis: fetuses of the different groups were analyzed by one-way ANOVA; if $p<0.05$, Fisher's LSD multiple comparison test was used to detect significant differences between individual groups: Posthoc comparisons that were significantly different are denoted by different capital letters on top of the bars (all $p<0.01$ ).

fetal growth retardation. However, plasma $\mathrm{Ca}, 1,25(\mathrm{OH})_{2} \mathrm{D}_{3}$ and osteocalcin concentrations were higher in $V D R+/-$ fetuses than in $w t$ fetuses, but were restored by the rescue diet to values measured in $w t$ fetuses.

The Ca content, and the mineralized bone volume on histomorphometry, of $V D R+/-$ fetuses were $45 \%$ and $41 \%$, respectively, of the values measured in $w t$ fetuses (Fig. 3 and 4). In addition, the number of TRAP-positive cells per bone area was raised by $144 \%$, compared with $w t$ fetuses. The rescue diet normalized the mineralized bone volume and the number of TRAP-positive cells, and raised the fetal Ca content to $83 \%$ of $w t$ values. No significant differences were found among the 3 groups in the hypertrophic chondrocyte area (ANOVA: $p=$ 0.07; data not shown).

\section{DISCUSSION}

$V D R-/-$ mice showed the anticipated abnormalities in bone mineral homeostasis. They were slightly hypocalcemic, with the expected compensatory increase in circulating $1,25(\mathrm{OH})_{2} \mathrm{D}_{3}$. Bone histomorphometry confirmed rickets (wide growth plates at the proximal tibia) and osteomalacia (abundant and wide osteoid seams at trabecular bone surfaces). The TRAP-positive surface was increased, suggestive of secondary hyperparathyroidism; in Tokyo- and Boston-VDR-null mice, histomorphometric indices of bone resorption were reportedly normal, as was the resorbing activity of osteoclasts generated in vitro $(14,23)$. Trabecular bone volume was slightly increased, confirming previous data $(14,23)$, but trabecular bone density on QCT was unaffected. However, cortical bone thickness and density on QCT was $10 \%$ to $15 \%$ lower than in $w t$ mice, which is in line with our findings in nutritionally vitamin
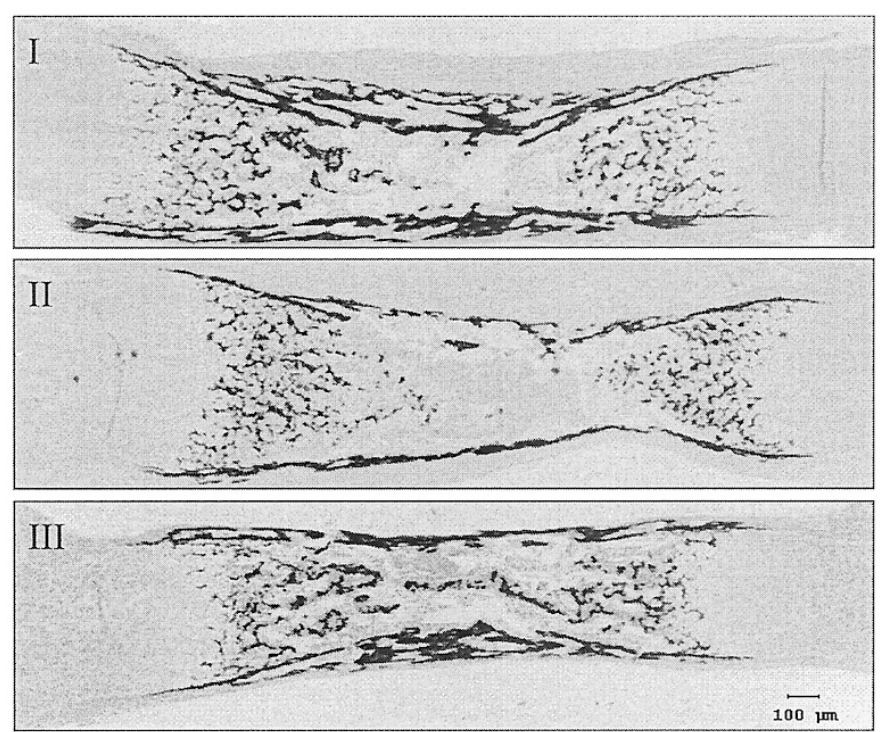

Figure 4. Representative sections of the tibia of d 18.5-fetal mice, stained according to von Kossa, in the $w t$ (I), VDR-null (II), and $V D R-/-$ rescue diet groups (III), showing that the mineralized bone volume is lower in fetuses of VDR-null mothers, but is normalized by the rescue diet; magnification $\times 40$.

D-deficient guinea-pigs (19). Finally, concentrations of CaBP$\mathrm{D}_{9 \mathrm{k}}$ in duodenum and kidney were reduced, as previously shown in several $V D R-/-$ strains at the mRNA and protein levels $(7,9,11)$.

The maternal response to pregnancy was comparable in $w t$ and $V D R-/-$ mice. An interactive effect for pregnancy was observed only for renal $\mathrm{CaBP}-\mathrm{D}_{9 \mathrm{k}}$, i.e., renal $\mathrm{CaBP}-\mathrm{D}_{9 \mathrm{k}}$ con- 
centrations increased in $w t$ but not in $V D R-/-$ pregnancies. The skeletal response to pregnancy was comparable, and included a suppression of bone formation parameters on histomorphometry, both static and dynamic, and an increase in trabecular bone volume on histomorphometry and in trabecular bone density on QCT. We have reported that histomorphometric bone formation parameters are also reduced markedly during late pregnancy in guinea pigs $(19,21)$. The increase in trabecular bone volume/density - shown by two independent methods - is difficult to explain, given that bone resorption does not appear to be altered by pregnancy; clearly, further research into this issue is needed. Duodenal $\mathrm{CaBP}_{-} \mathrm{D}_{9 \mathrm{k}}$ concentrations rose during pregnancy, compatible with the pregnancy-driven stimulation of active intestinal $\mathrm{Ca}$ absorption (2), but remained $40 \%$ lower in $k o$ than in $w t$ mice. These findings confirm data showing that the active intestinal $\mathrm{Ca}$ absorption increases during late pregnancy in both D-replete and Ddeficient rats, but is still $40 \%$ lower in D-deficient rats (24).

Fetuses of $V D R-/-$ mice were slightly growth-retarded, and were hypomineralized: both the fetal Ca content, corrected for weight, and the mineralized bone in tibial sections, were reduced. But the hypertrophic chondrocyte area was not affected, suggesting that, while bone maturation is normal, mineralization is impaired because of lower mineral availability, much the same as we have previously documented in fetuses of strontium-fed rats (18). In addition, the fetuses were hypercalcemic, with a 5 -fold increase in $1,25(\mathrm{OH})_{2} \mathrm{D}_{3}$ concentrations. We surmise that the latter is the result of high maternal $1,25(\mathrm{OH})_{2} \mathrm{D}_{3}$ levels. Indeed, maternal and fetal $1,25(\mathrm{OH})_{2} \mathrm{D}_{3}$ concentrations are highly correlated in human (25), rat (18) and guinea pig pregnancies $(19,21)$. Whether the hypercalcemia is related to elevated $1,25(\mathrm{OH})_{2} \mathrm{D}_{3}$ levels in utero is uncertain, but cannot be excluded since the fetuses were genotypically heterozygous and thus potentially responsive to $1,25(\mathrm{OH})_{2} \mathrm{D}_{3}$. In fetal sheep, nephrectomy reduced both $1,25(\mathrm{OH})_{2} \mathrm{D}_{3}$ and $\mathrm{Ca}$ levels (26), whereas fetal nephrectomy in rats reduced $1,25(\mathrm{OH})_{2} \mathrm{D}_{3}$ but not Ca levels (27). The fetal hypercalcemia may also be explained by secondary hyperparathyroidism (19), since we found an increase in the osteoclastic cell number on histomorphometry of the tibia. However, we were unable to measure PTH reliably in the fetuses. Plasma osteocalcin levels were higher in fetuses of $k o$ mice, inferring that osteoblast number or/and activity was increased as well; this could not be corroborated by histomorphometry, because of technical limitations.

A high $\mathrm{Ca} / \mathrm{P} /$ lactose diet rescues the metabolic and skeletal abnormalities of VDR $k o$ mice, including a normalization of histomorphometrical parameters $(13,14)$. We confirm these data in pregnant ko mice: the hypocalcemia was reversed, as well as the reduced cortical bone density on QCT. But the rescue diet lowered $\mathrm{CaBP}-\mathrm{D}_{9 \mathrm{k}}$ concentrations in duodenum and kidney further; the duodenum data confirm previous results in nonpregnant Leuven VDR-ko mice (9), whereas reversal of decreased $\mathrm{CaBP}-\mathrm{D}_{9 \mathrm{k}}$ was reported in Boston VDR ko mice on the rescue diet (10). Our results are compatible with the paradigm that the high $\mathrm{Ca} / \mathrm{P} /$ lactose diet promotes the paracellular, nonsaturable $\mathrm{Ca}$ transport in the intestine, which is VDR- and $\mathrm{CaBP}-\mathrm{D}_{9 \mathrm{k}}$-independent (3), and represses VDR-dependent $\mathrm{Ca}$ absorption.

In the fetuses, the rescue diet reversed the hypomineralization, the increased osteoclastic cell number in tibial sections, the increased plasma osteocalcin and $1,25(\mathrm{OH})_{2} \mathrm{D}_{3}$ levels, and the hypercalcemia. How to explain these data? First, since the fetuses were all genotypically heterozygous for the VDR, the genotype cannot be the sole explanation for the bone and mineral phenotype. Second, the rescue diet raises the maternal intestinal passive $\mathrm{Ca}$ absorption, which is a linear function of the $\mathrm{Ca}$ intake (3), and may thereby promote the $\mathrm{Ca}$ availability to the fetuses. Hence, the suboptimal VDR-dependent $\mathrm{Ca}$ absorption would be substituted by $\mathrm{Ca}$ intake-entrained VDRindependent $\mathrm{Ca}$ absorption to ensure normal fetal mineralization. Third, $V D R+/-$ fetuses on the regular diet had high $1,25(\mathrm{OH})_{2} \mathrm{D}_{3}$ levels, and there is some evidence for a 'toxic' effect of $1,25(\mathrm{OH})_{2} \mathrm{D}_{3}$ on bone development in utero. Indeed, in experiments with 24-hydroxylase gene ko mice, homozygous mutant newborns of homozygous mutant mothers showed deficient mineralization, which was rescued in newborns that also lacked the VDR gene, inferring that high circulating $1,25(\mathrm{OH})_{2} \mathrm{D}_{3}$ acting through the VDR was responsible for the defective mineralization (28). Finally, the putative hyperparathyroidism of $V D R+/-$ fetuses on the regular diet may also be involved in the hypomineralization, through increased bone resorption (29).

The fetal growth retardation was not reversed by the rescue diet; in fact, $V D R+/-$ fetuses on the rescue diet weighed less than $V D R+/-$ fetuses on the regular diet. The data suggest that the VDR genotype may be a determinant of fetal growth in mice. In humans, there is some evidence that VDR allelic variants are associated with height at birth and postnatal growth (30). There may also be a link with the lower maternal body weight in the rescue diet group, a finding for which we have no explanation. In nutritionally D-deficient guinea pigs, we previously documented that a comparable rescue diet reversed both fetal growth retardation and hypomineralization (19).

From our data, placental $\mathrm{CaBP}-\mathrm{D}_{9 \mathrm{k}}$ expression does not appear to be VDR-dependent, although this needs to be confirmed at the mRNA transcript level; however, our results are consistent with previous data in nutritionally D-deficient rats (16). CaBP-D $9 \mathrm{k}$ protein expression was particularly intense in the visceral layer of the intraplacental yolk sac -which may well be crucial for maternal-fetal Ca transfer in mice (31) - and to a lesser extent in the trophoblastic giant cells, as previously reported (32).

This study has several limitations. First, we did not include a rescue diet experiment in $w t$ or nonpregnant $V D R-/-$ - mice. Second, it would be of interest to expand the study and compare $V D R+/-$ and $V D R-/-$ fetuses from matings of $V D R-/-$ females and $V D R+/-$ males. Third, other proteins involved in intestinal $\mathrm{Ca}$ absorption, such as the epithelial $\mathrm{Ca}^{2+}$ channels, were not assessed here.

Experiments in VDR ko mice have demonstrated that the prime effect of the VDR is the stimulation of intestinal $\mathrm{Ca}$ absorption and $\mathrm{Ca}$ availability. Feeding $V D R-/-$ mice a high $\mathrm{Ca} / \mathrm{P} /$ lactose diet normalizes not only the hypocalcemia, hy- 
perparathyroidism and the skeletal phenotype, but also fertility in some VDR ko strains (15) and the abnormalities in the immune system (33). The present data add to this body of knowledge, showing that fetuses of mothers with a disrupted VDR gene have a defective mineralization, and is reversed by a rescue diet that also normalizes maternal and fetal $1,25(\mathrm{OH})_{2} \mathrm{D}_{3}$ levels.

Acknowledgments. The authors are grateful to Professor D. Vanderschueren for the use of the QCT, and Professor R. Pijnenborg for his help with the CaBP-D ${ }_{9 K}$ immunohistochemistry. We also thank L. Vercruysse, R. Janssens, W. Coopmans, and I. Jans for their valuable advice and help.

\section{REFERENCES}

1. Ritchie LD, Fung EB, Halloran BP, Turnlund JR, Van Loan MD, Cann CE, King JC 1998 A longitudinal study of calcium homeostasis during human pregnancy and lactation and after resumption of menses. Am J Clin Nutr 67:693-701

2. Zhu Y, Goff JP, Reinhardt TA, Horst RL 1998 Pregnancy and lactation increase vitamin D-dependent intestinal membrane calcium adenosine triphosphatase and calcium binding protein messenger ribonucleic acid expression. Endocrinology 139:3520-3524

3. Bronner F, Pansu D, Stein WD 1986 An analysis of intestinal calcium transport across the rat intestine. Am J Physiol 250:G561-G569

4. Bronner F 1989 Renal calcium transport: mechanisms and regulation: an overview. Am J Physiol 257:F707-F711

5. Glazier JD, Atkinson DE, Thornburg KL, Sharpe PT, Edwards D, Boyd RDH, Sibley CP 1992 Gestational changes in $\mathrm{Ca}^{2+}$ transport across rat placenta and mRNA for calbindin $_{9 \mathrm{~K}}$ and $\mathrm{Ca}^{2+}$-ATPase. Am J Physiol 263:R930-R935

6. Hoenderop JG, Willems PH, Bindels RJ 2000 Toward a comprehensive molecular model of active calcium reabsorption. Am J Physiol 278:F352-360

7. Yoshizawa T, Handa Y, Uematsu Y, Takeda S, Sekine K, Yoshihara Y, Kawakam T, Arioka K, Sato H, Uchiyama Y, Masushige S, Fukamizu A, Matsumoto T, Kato S 1997 Mice lacking the vitamin D receptor exhibit impaired bone formation, uterine hypoplasia and growth retardation after weaning. Nat Genet 16:391-396

8. Li YC, Pirro AE, Amling M, Delling G, Baron R, Bronson R, Demay MB 1997 Targeted ablation of the vitamin D receptor: an animal model of vitamin D-dependent rickets type II with alopecia. Proc Natl Acad Sci USA 94:9831-9835

9. Van Cromphaut SJ, Dewerchin M, Hoenderop JG, Stockmans I, Van Herck E, Kato S, Bindels RJ, Collen D, Carmeliet P, Bouillon R, Carmeliet G 2001 Duodenal calcium absorption in vitamin D receptor-knockout mice: functional and molecular aspects. Proc Natl Acad Sci USA 98:13324-13329

10. Li YC, Pirro AE, Demay MB 1998 Analysis of vitamin D-dependent calcium-binding protein messenger ribonucleic acid expression in mice lacking the vitamin D receptor. Endocrinology 139:847-851

11. Li YC, Bolt MJG, Cao L-P, Sitrin MD 2001 Effects of vitamin D receptor inactivation on the expression of calbindins and calcium metabolism. Am J Physiol 281:E558E564

12. Thomasset M, Parkes CO, Cuisinier-Gleizes $\mathrm{P} 1982$ Rat calcium-binding proteins distribution, development, and vitamin D dependence. Am J Physiol 243:E483-E488

13. Li YC, Amling M, Pirro AE, Priemel M, Meuse J, Baron R, Delling G, Demay MB 1998 Normalization of mineral ion homeostasis by dietary means prevents hyperparathyroidism, rickets, and osteomalacia, but not alopecia in vitamin D receptorablated mice. Endocrinology 139:4391-4396

14. Amling M, Priemel M, Holzmann T, Chapin K, Rueger JM, Baron R, Demay MB 1999 Rescue of the skeletal phenotype of vitamin D receptor-ablated mice in the setting of normal mineral ion homeostasis: formal histomorphometric and biomechanical analyses. Endocrinology 140:4982-4987

15. Johnson LE, DeLuca HF 2001 Vitamin D receptor null mutant mice fed high levels of calcium are fertile J Nutr 131:1787-1791

16. Glazier JD, Mawer EB, Sibley CP 1995 Calbindin- $D_{9 K}$ gene expression in rat chorioallantoic placenta is not regulated by 1,25 -dihydroxyvitamin $D_{3}$. Pediatr Res 37:720-725

17. Verhaeghe J, Van Herck E, Van Bree R, Van Assche FA, Bouillon R 1989 Osteocalcin during the reproductive cycle in normal and diabetic rats. J Endocrinol 120:143-151

18. Verhaeghe J, van Bree R, van Herck E, Rummens K, Vercruysse L, Bouillon R, Pijnenborg R 1999 Pathogenesis of fetal hypomineralization in diabetic rats: evidence for delayed bone maturation. Pediatr Res 45:209-217

19. Rummens K, van Bree R, Van Herck E, Zaman Z, Bouillon R, Van Assche FA, Verhaeghe J 2002 Vitamin D-deficiency in guinea pigs: exacerbation of bone phenotype during pregnancy and disturbed fetal mineralization, with recovery by $1,25(\mathrm{OH})_{2} \mathrm{D}_{3}$ infusion or dietary calcium-phosphate supplementation Calcif Tissue Int 71:364-375

20. Verhaeghe J, Oloumi G, Van Herck E, van Bree R, Dequeker J, Einhorn TA, Bouillon R 1997 Effects of long-term diabetes and/or high-dose 17 $\beta$-estradiol on bone formation, bone mineral density, and strength in ovariectomized rats. Bone 20:421-428

21. Rummens K, Van Herck E, van Bree R, Bouillon R, Van Assche FA, Verhaeghe J 2000 Dietary calcium and phosphate restriction in guinea-pigs during pregnancy: fetal mineralization induces maternal hypocalcaemia despite increased $1 \alpha, 25$ dihydroxycholecalciferol concentrations. Br J Nutr 84:495-504

22. Parfitt AM, Drezner MK, Glorieux FH, Kanis JA, Malluche H, Meunier PJ, Ott SM, Recker RR 1987 Bone histomorphometry: standardization of nomenclature, symbols, and units. J Bone Miner Res 2:595-610

23. Takeda S, Yoshizawa $T$, Nagai $Y$, Yamato $H$, Fukumoto $S$, Sekine $K$, Kato $S$, Matsumoto T, Fujita T 1999 Stimulation of osteoclast formation by 1,25dihydroxyvitamin $\mathrm{D}$ requires its binding to vitamin $\mathrm{D}$ receptor (VDR) in osteoblastic cells: studies using VDR knockout mice. Endocrinology 140:1005-1008

24. Halloran BP, DeLuca HF 1980 Calcium transport in small intestine during pregnancy and lactation. Am J Physiol 239:E64-E68

25. Bouillon R, Van Assche FA, Van Baelen H, Heyns W, De Moor P 1981 Influence of the vitamin D-binding protein on the serum concentration of 1,25-dihydroxyvitamin $\mathrm{D}_{3}$. J Clin Invest 67:589-596

26. Moore ES, Langman CB, Favus MJ, Coe FL 1985 Role of fetal 1,25 dihydroxyvitamin D production in intrauterine phosphorus and calcium homeostasis. Pediatr Res 19:566-569

27. Chalon S, Garel JM 1985 Plasma calcium control in the rat fetus. II. Influence of fetal hormones. Biol Neonate 48:323-328

28. St-Arnaud R, Arabian A, Travers R, Barletta F, Raval-Pandya M, Chapin K, Depovere J, Mathieu C, Christakos S, Demay MB, Glorieux FH 2000 Deficient mineralization of intramembranous bone in vitamin D-24-hydroxylase-ablated mice is due to elevated 1,25-dihydroxyvitamin $\mathrm{D}$ and not to the absence of 24,25dihydroxyvitamin D. Endocrinology 141:2658-2666

29. Kovacs CS, Ho-Pao CL, Hunzelman JL, Lanske B, Fox J, Seidman JG, Seidman CE, Kronenberg HM 1998 Regulation of murine fetal-placental calcium metabolism by the calcium-sensing receptor. J Clin Invest 101:2812-2820

30. Lorentzon M, Lorentzon R, Nordström P 2000 Vitamin D receptor gene polymorphism is associated with birth height, growth to adolescence, and adult stature in healthy Caucasian men: a cross-sectional and longitudinal study. J Clin Endocrinol Metab 85:1666-1671

31. Kovacs C, Chafe LL, Woodland ML, McDonald KR, Fudge NJ, Wookey PJ 2002 Calcitropic gene expression suggests a role for the intraplacental yolk sac in maternalfetal calcium exchange. Am J Physiol 282:E721-E732

32. Shamley DR, Veale G, Pettifor JM, Buffenstein R 1996 Trophoblastic giant cells of the mouse placenta contain calbindin- $\mathrm{D}_{9 \mathrm{k}}$ but not the vitamin $\mathrm{D}$ receptor. J Endocrinol 150:25-32

33. Mathieu C, Van Etten E, Cysemans C, Decallonne B, Kato S, Laureys J, Depovere J, Valckx D, Verstuyf A, Bouillon R 2001 In vitro and in vivo analysis of the immune system of vitamin D receptor knockout mice. J Bone Miner Res 6:2057-2065 